\title{
The Effect of Ethnocentrism and Product Knowledge on The Buying Interest of “Tembe Me'e Donggo"Products
}

\author{
1 Sri Ernawati, ${ }^{2}$ Kamaluddin, ${ }^{3}$ Ita Purnama \\ 1,2,3STIE Bima, Bima, Indonesia \\ 1ㅗriernawati.stiebima@gmail.com, ${ }^{2}$ kamaluddin@gmail.com, 3 itapurnama@gmail.com
}

\begin{tabular}{|c|c|}
\hline Article Info & bstract \\
\hline $\begin{array}{l}\text { Article History } \\
\text { Received: July 12, } 2018 \\
\text { Accepted: September } 30, \\
2018\end{array}$ & \multirow{2}{*}{$\begin{array}{l}\text { This current research explores the effect of ethnocentrism and } \\
\text { productnowledge on the buyinginterest of the products ofTembe Mee } \\
\text { Donggo. The research aims: 1) to determine the positive and significant } \\
\text { effect of ethnocentrism on buying interest in tembe me'e Donggo products; 2) } \\
\text { to determine the positive and significant effect of productknowledge on } \\
\text { buying interest intembe me'e Donggo products; and 3) to determine the } \\
\text { positive and significant influence of ethnocentrism and productknowledge on } \\
\text { buying interest intembe me'e Donggo products. The methodology used in this } \\
\text { research is associative in nature, using questionnaires, observations, and } \\
\text { library research to collect data, and a multiple linear regression analysis to } \\
\text { analyze the data. The research took place in Donggo district of Bima regency } \\
\text { during the two months of February and March of 2018. The sample, taken } \\
\text { using purposive sampling technique,include50 people of Donggo, who had } \\
\text { ever used and bought tembe me'e Donggo products. The results reveal that: } \\
\text { 1) ethnocentrism has a positive and significant effect on the buying interest } \\
\text { of tembe me'e Donggo products; 2) product knowledge has a positive and } \\
\text { significant effect to the buying interest of tembe mee Donggo products; and } \\
\text { 3) ethnocentrism and product knowledge together have a positive and } \\
\text { significant effect on the buying interest of tembe me'e Donggo products. }\end{array}$} \\
\hline $\begin{array}{l}\text { Keywords } \\
\text { Ethnocentrism; Product } \\
\text { Knowledge; Buying Interest }\end{array}$ & \\
\hline & \\
\hline
\end{tabular}

\section{INTRODUCTION}

Indonesia is a country known as an exporter of woven cloth. Almost all provinces in Indonesia have woven cloth that become a mainstay because it reflects the culture and natural conditions of each region. One of them is West Nusa Tenggara Province which has varieties of woven clothes called Sasambo (Sasak, Samawa, Mbojo). The desire of people to use woven clothis very high because it has become tradition even a trend. It can be seen from the use of woven cloth itself that can be used for every activity either formal nor informal, even people do not pay attention of the price to get the woven cloth with a relatively high price.

To response the low perceived quality of the community, the government in 2009 issued instructions on increasing the use of domestic products and procurement of government commodity or service. In line with these instructions, the government is promoting I Love Indonesia (Aku Cinta Indonesia [ACI] program. The objective of the ACI Program itself is in line with the concept of consumer ethnocentrism. Consumer ethnosetrism is a term which is taken from the concept of ethnocentrism. Ethnocentrism itself is an understanding where there are negative prejudices to other groups and contemplate the group itself as the most positive reference.

Donggo communityor Dou Mbojo is the oldest inhabitant of Bima region compared to the other tribes. One of woven clothes produced by the communityis Tembe Mee 
Donggo which has a uniquemotif. The cloth materialbecomes so appealing, thus widely demanded by customers locally and internationally. What makes it more uniqueis the way it is traditionally and manually colored. The coloring process may take up to two months, making use of latex tree that through marinating process becomes black (or me'e in local language). Nowadays, Tembe Me'e has been used as Kababu (Donggo's traditional clothes), Tembe Compo(sarong) and Tembe Dala(shawl). The cloth is mainly produced for family use or necessity. For people in Mbawa, as an integral part of Donggo community, wearing Tembe Me'e cloth and Kababu clothes for formal occasions such as weddings is a mandatory.

Based on the background, the researchers are interested to explore the effect of ethnocentrism and knowledge of products on the interest of buying the products ofTembe Mee Donggo.

\section{METHOD}

This type of research is associative in nature. The site of research was in Donggo district of Bima regency. Study period ranged from February 1 to July 31, 2018. The measurement of variablesin thisresearch study was carried out by using a score that refers to the use of likert scale.The research population included all members of Donggo community who had bought and used tembe me'e Donggo whose numbers can hardly be recognized due to scant of data available. The total sample included50 people, taken using purposive samplingtechnique. Data were collectedthrough the distribution of questionnaires to the people of Donggo living in Donggo district and who had bought and used tembe me'e Donggo. Other methods of collecting data included observation and library library.

To analyze the data, the researchers used a multiple linear regression analysis in order to identify the effect of both ethnocentrism and product knowledge on buying interest of tembe mee Donggo products. For the data analysis, the researchers used multiple linear regression equation model as follows:

$$
\begin{aligned}
& Y=a+b_{1} x_{1}+b_{2} x_{2} \\
& \text { Where: } \\
& Y=\text { Buying interest } \\
& X_{1}=\text { Ethnocentrism } \\
& X_{2}=\text { Product knowledge } \\
& a=\text { Constant value } \\
& b_{1}, b_{2}=\text { regression of coeffisient }
\end{aligned}
$$

\begin{tabular}{|c|c|c|c|c|c|}
\hline \multirow[t]{2}{*}{ CoefficientsaModel } & \multicolumn{2}{|c|}{$\begin{array}{c}\text { Unstandardised } \\
\text { Coefficients }\end{array}$} & $\begin{array}{c}\text { Standardised } \\
\text { Coefficients }\end{array}$ & \multirow[t]{2}{*}{$\mathrm{t}$} & \multirow[t]{2}{*}{ Sig. } \\
\hline & B & Std. Error & Beta & & \\
\hline \multirow[b]{3}{*}{ knowledge } & 1.210 & .764 & & 1.585 & .020 \\
\hline & .134 & .020 & .283 & 6.569 & .000 \\
\hline & 1.029 & .060 & .736 & 17.063 & .000 \\
\hline
\end{tabular}

\section{RESULT}

\section{Multiple Linear Regression}

Multiple regression analysis was chosen to analyze the submissionhypothesis in this research. Testing was carried out by using SPSS 16.00 for Windows program.

\section{Table 1. Multiple Regression Coefficients Test Results}

Source: Primary Data processed 2018 
From the aforementioned results of regression analysis, it can be seen the multiple regression equation as follows:

$$
\mathrm{Y}=1.210+0.134 \mathrm{X}_{1}+1.029 \mathrm{X}_{2}
$$

The result of the equation can be explained as follows:

a. Constant value is 1.210, which can be interpreted as follows: if the ethnocentrism and product knowledgevariable arerepputed zero, then buying interest will be 1.210.

b. The value of beta coefficient on the ethnocentrism variable is 0.134 , meaning that every change of ethnocentrism variable (X1) of one unit will effect in buyinginterestchange as big as 0.134 unit, assuming another variable stays unchanged.The increase of one unit in the ethnocentrism variable will increase buyinginterestin the amount of 0.134 unit.

c. The value of beta coefficient on the product knowledgevariable of 1.029 , means that every change of product knowledge(X2) variable for one unit will resultin buying interest change as big as 1.029 unitsassuming another variable remains unchanged. The increaseof one unit in the product knowledgevariable will increase buying interestin the amount of 1.029 unit.

Table 2. Multiple correlation test results

\begin{tabular}{|ll|l|l|l|}
\hline \multicolumn{2}{|c|}{ Correlations } & \multicolumn{1}{|c|}{$\begin{array}{c}\text { Buying } \\
\text { interest }\end{array}$} & Ethnocentrism & \multicolumn{1}{c|}{$\begin{array}{c}\text { Product } \\
\text { knowledge }\end{array}$} \\
\hline Pearson & Buying Interest & 1.000 & .905 & .976 \\
Correlation & Ethnocentrism & .905 & 1.000 & .844 \\
& Product knowledge & .976 & .844 & 1.000 \\
& Buying Interest &. & .000 & .000 \\
Sig. (1-tailed) & Ethnocentrism & .000 &. & .000 \\
& Product knowledge & .000 & .000 &. \\
N & Buying Interest & 50 & 50 & 50 \\
& Ethnocentrism & 50 & 50 & 50 \\
& Product knowledge & 50 & 50 & 50 \\
\hline
\end{tabular}

Source: Primary Data processed 2018

Based on the aforementioned table of multiple product moment correlation test results, it can be explained the correlation between ethnocentrism variable ( $\left.\mathrm{X}_{1}\right)$ and product knowledge $\left(\mathrm{X}_{2}\right)$ to buying interest $(\mathrm{Y})$ as follows:

Ryx $1 \times 2=$ There is a correlation or relationship between ethnocentrism ( $\left.\mathrm{X}_{1}\right)$, product knowledge $\left(\mathrm{X}_{2}\right)$ and buying interest $(\mathrm{Y})$ with a correlation value of 0.476 which can be categorized as having a powerful relationship, and based on the significance test, the value shows 0.000 which means the association of the three variables is significant.

Ryx1 = There is a correlation or relationship between ethnocentrism $\left(\mathrm{X}_{1}\right)$ and buying interest ( $\mathrm{Y}$ ) with a value is 0.905 which can be categorized as having a powerful relationship, and based on the significance test, the result shows 0.000 value which means the association of both variables issignificant.

Ryx2 = There is a correlation or relationship between product knowledge $\left(\mathrm{X}_{2}\right)$ and buying interest $(\mathrm{Y})$ with a value of 0.976 which can be categorized as having a powerful relationship, and based on the significance test, the result shows 0.000 value which means the association of both variables issignificant.

Table 3. Determination Coefficient Test Result Summary Modelb.

\begin{tabular}{|l|l|l|l|l|} 
Model & R & R Square & Adjusted R & Std. Error of \\
\hline
\end{tabular}




\begin{tabular}{|l|l|l|l|l|}
\hline & & & Square & the Estimate \\
\hline 1 & $.987^{\mathrm{a}}$ & .975 & .974 & .549 \\
\hline
\end{tabular}

a. Predictors: (Constant), Product Knowledge, Ethnocentrism

b. Dependent Variable: Buying Interest

Adjusted $\mathrm{R}^{2}$ test result in this study obtained a value as big as 0.975 . It shows that buyinginterest $(\mathrm{Y})$ is influenced by theethnocentrism (X1) and product knowledge $\left(\mathrm{X}_{2}\right)$ of $97.5 \%$, while the rest of $2.5 \%$ is influenced by another factors that are not included in this research.

\section{Hypothesis Test Results}

Furthermore, to find out whether the hypothesis proposed in this study be accepted or rejected, the hypothesis testingwas conducted by using t-test and F-test. The result of hypothesis testing is described as follows:

T-test Result (partially)

Table 4. Coefficients ${ }^{a}$

\begin{tabular}{|c|c|c|c|c|c|c|}
\hline & \multirow[t]{2}{*}{ Model } & \multicolumn{2}{|c|}{$\begin{array}{l}\text { Unstandardized } \\
\text { Coefficients }\end{array}$} & \multirow{2}{*}{$\begin{array}{c}\begin{array}{c}\text { Standardiz } \\
\text { ed } \\
\text { Coefficient } \\
\text { s }\end{array} \\
\text { Beta } \\
\end{array}$} & \multirow[t]{2}{*}{$\mathbf{t}$} & \multirow[t]{2}{*}{ Sig. } \\
\hline & & B & Std. Error & & & \\
\hline \multirow{3}{*}{1} & (Constant) & 1.210 & .764 & & 1.585 & .020 \\
\hline & ethnocentrism & .134 & .020 & .283 & 6.569 & .000 \\
\hline & knowledge & 1.029 & .060 & .736 & 17.063 & .000 \\
\hline
\end{tabular}

H1: It is estimated theethnocentrism has a positive and significant effect on the buying interest of tembe me'e Donggoproducts.

The statistic result of t-test for ethnocentrism variable obtained is $t_{\text {count }}$ of 6.569 with $t_{\text {table }}$ value is $1.676(2.536>1.676)$ with significance value equal to 0.00 less than 0.05 $(0.00<0.05)$, and the regression coefficient has positive value as big as 0.134 ; then the hypothesis statesthat "ethnocentrism has a positive and significant effect on the buying interest of tembe me'e Donggoproducts" is proven.

H2:It is suspected that product knowledge has a positive and significant influence on the buying interest of tembe me'e Donggoproducts.

The statistic result of t-test for product knowledge obtainedist count $_{\text {of } 17.063 \text { with }}$ $t_{\text {table }}$ value is $1.676(17.063,1.676)$ with significance value equals to 0.00 less than 0.05 $(0.00<0.05)$, and the regression coefficient has positive value as big as 1.029 ; then the hypothesis states that "product knowledgehas a positive and significant effect on the buying interest of tembe me'e Donggoproducts" is proven.

F-Test Results (Simultaneously)

Table 5. F-Test Results (Simultaneously)

ANOVAa

\begin{tabular}{|c|l|l|l|l|l|l|}
\hline \multicolumn{1}{|c|}{ Model } & \multicolumn{1}{c|}{$\begin{array}{c}\text { Sum of } \\
\text { Squares }\end{array}$} & \multicolumn{1}{|c|}{ Df } & $\begin{array}{c}\text { Mean } \\
\text { Square }\end{array}$ & \multicolumn{1}{|c|}{ F } & \multicolumn{1}{c|}{ Sig. } \\
\hline \multirow{4}{*}{1} & Regression & 549.138 & 2 & 274.569 & 912.49 & $.000 \mathrm{~b}$ \\
& Residual & 14.142 & 47 & .301 & 1 & \\
& Total & 563.280 & 49 & & & \\
\hline
\end{tabular}


a. Dependent Variable: buying interest

b. Predictors: (Constant), product knowledge, ethnocentrism

Source: Primary Data processed 2018

H3: It is estimated theethnocentrism and product knowledgeas together have a positive and significant effect on the buying interest of tembe me'e Donggoproducts.

The test result obtained is $F_{\text {count }}$ value of 912.491 with $F_{\text {table }}$ value is $3.19(912,491$ $>3,19)$ with a significance equal to $0.000(0.000<0.05)$. Since the significance value is less than $0.05(0.000<0.05)$, it can be concluded that "ethnocentrism and productknowledge together have a positive and significant effect on the buying interest of tembe me'e Donggo products" is proven.

\section{CONCLUTION}

The conclusions of this study are as follow: (1) Ethnocentrism has a positive and significant effect on the buying interest of tembe me'e Donggo products, where the value of tcountis 6.569 with the ttable value equals to $1.676(2.536>1.676)$ with a significance value as big as 0.00 is less than $0.05(0.00<0.05)$, (2) Product knowledge has a positive and significant effect to the buying interest of tembe mee Donggo products, where the value of tcount value obtained is17,063 with the ttable value equals to $1.676(17.063>1.676)$ with a significance value equals to 0.00 is less than $0.05(0.00$ <0.05), (3) Ethnocentrism and product knowledge together have a positive and significant effect on the buying interest of tembe me'e Donggo products, where Fcount value is 912.491 with Ftable value equals to 3.19 (912.491 >3.19) with a significancevalue equals to $0.000(0.000<0.05)$.

\section{REFERENCE}

[1] Amirullah. (2013). Metodologi Penelitian Manajemen, Malang:Bayu Media

[2] Basu Swastha dan Irawan. (2001). Manajemen Pemasaran Modern, Yogyakarta: Liberty

[3] Dewi. I. A. M. Lakmini dan Sulistywati, Eka. Pengaruh gaya hidup dan sikap Ethnocentrism terhadap niat beli konsumen. E-Jurnal Manajemen Unud, Vol 5.No 8 2016:5128-5154. ISSN 2302-8912.

[4] Fadila, Dewi dan Rasyid Nirwan. (2012). Pengaruh Ethnocentrism Konsumen Terhadap Keterlibatan Pengambilan Keputusan Pembelian Produk. Jurnal Orasi Bisnis Edisi ke-VII, Mei 2012.

[5] Ferdinand, Augusty. (2014). Metode Penelitian Manajemen, Semarang, Badan Penerbit Universitas Diponegoro.

[6] Ghozali, Imam. (2005). Aplikasi Analisis Multivariate dengan program SPSS, Badan Penerbit Universitas Diponegoro, Semarang.

[7] Hair, J. F., et al. (2007). Multivariate Data Analysis. 6th Edition. New Jersey : Pearson Education Inc.

[8] Kemendag. (2014). Gebyar Kampanye ACI 100 Persen Aku Cinta Indonesia. Diunduh dari ttp://ditjenpdn.kemendag.go.id/id/news/2014/08/09/gebyar-kampanyeaci100-persen-aku-cinta-indonesia

[9] Nugroho J. Setiadi. (2008). Perilaku Konsumen :Konsep dan Impilikasi Untuk Strategi dan Penelitian Pemasaran. Jakarta : Kencana 
[10] Lin. N.H and Lin. B.S. (2007). The effect Of brand image and product knowledge on purchase intention moderated by price discount. Journal of international management studies.

[11] Listiana, Erna. (2012). Pengaruh Country Of Origin terhadap Perceived Quality Dengan Moderasi Etnosentris Konsumen. Jurnal Administrasi Bisnis(2012), Vol.8, No.1: hal. 21-47.

[12] McCarthy, E Jerome dan William D. Pereault Jr. (2003). Dasar-Dasar Pemasaran, Edisi Bahasa Indonesia, Jakarta : Penerbit Erlangga.

[13] Ping Qing, Antonio Lobo, and Li Chongguang. (2012). The impact of lifestyle and ethnocentrism on consumers' purchase intentions of fresh fruit in China. Journal of Consumer Marketing, Emerald Group Publishing Limited Vol. 29 No 1. h. 43-51

[14] Pradesta. B. Rima. "Pengaruh Ethnocentrisme, Brand Image Dan Product Knowledge Terhadap Keputusan Pembelian Produk Pakaian Jadi Impor". E-Jurnal Manajemen Unud, Vol. 5, No.8, 2016:5128-5154 ISSN : 2302-8912

[15] Satria. B. Ariz dan Oetomo W. Hening "Pengaruh Kualitas Pelayanan, Product Knowledge dan Wom Terhadap Proses Pengambilan Keputusan Pembelian". Jurnal Ilmu dan Riset Manajemen : Volume. 5, Nomor. 5, Mei 2016 ISSN : 2461-0593

[16] Schiffman, L.G. and Kanuk, L.L. (2000). Consumer Behavior. Pearson Education

[17] Shankarmahesh, N. (2006). Consumer Ethnocentrism : An Integrative Review Of Its Antecedents And Consequences. International Marketing Review, Vol 23, No 2, pp 146172

[18] Sharma, S., Shimp, T.A. and Shin, J. (1995). Consumer ethnocentrism: a test of antecedents and moderators, Journal of the Academy of Marketing Science, Vol. 23, No. 1, pp. 26-37.

[19] Shimp. T. A., Sharma. S. (1987). Consumer ethnocentrism:construction and validation of the CETSCALE. Journal of marketing research. 24, (3), pp $280-289$

[20] Sugiyono. (2005). Statistika untukpenelitian. Bandung: Alfabeta

[21] Sugiyono. (2007). Metode Penelitian Kuantitatif Kualitatif dan R\&D. Bandung: Alfabeta.

[22] Tifany dan Moningka Clara "Hubungan Konsumen Ethnocentrisme Dengan Perceived Quality Terhadap Produk Lokal Pada Usia Dewasa Muda Di Jakarta". PSIBERNETIKA Vol. 8 No. 2 Oktober 2015

[23] Tjiptono. F., Chandra. Y., Diana. A. (2004). Marketing Scales. Yogyakarta : Andi

[24] Umar, Husein. (2002). Metode riset bisnis. Jakarta: PT. Gramedia Pustaka Utama.

[25] Wang CL, Chen ZX. (2004). Consumer Ethnocentrism and Willingness to Buy Domestic Products in Developing Country Setting Testing Moderating Effects. Journal of Consumer Marketing.Volume 21 No. 6. Page 391-400

[26] Wang, Yai, H., Tsai, Cing, F. (2014). The Relationship between brand image and purchase intention: evidence from award winning mutual funds. The International. Journal of Business and Finance Research, 8 (2), 27-40. 